\title{
CHEMISTRY EDUCATION STUDENT RESPONSE TOWARD GENERAL BIOLOGY COURSE: A DESCRIPTIVE STUDY
}

\author{
Diyyan Marneli* and Lailatul Husni \\ Department of Biology Education, Faculty of Tarbiyah and Science Education, \\ State Islamic Institute of Batusangkar, West Sumatera, Indonesia. \\ *Corresponding e-mail: diyyanmarneli@iainbatusangkar.ac.id
}

\begin{abstract}
Chemistry and biology are interrelated branches of science, but students majoring in Chemistry Education are often considering as less ability to understand several biological concepts. The study aim was to obtain the information about the response of Chemistry Education students on the General Biology course. The research was a descriptive study conducted in August to December 2017 in which the subjects were twenty-four first-semester students of Chemistry Education who take General Biology course at Faculty of Tarbiyah and Teaching Sciences, State Islamic Institute of Batusangkar, West Sumatera. The instrument used was the questionnaire of student responses on the General Biology course. The analysis used was a descriptive statistical analysis by using percentage. The best response of students on the General Biology course was on assessment transparency aspect, while the lowest was on lecture attractiveness aspect. The conclusion of this research showed that the student response was considered as good criteria. Although from Department of Chemistry Education, most students give positive responses to the General Biology course. Information obtained from this study can be used as a basis to improve the quality of the General Biology course, especially in the Department of Chemistry Education.
\end{abstract}

Keywords: Chemistry, general biology, student's response

(C) 2018 Department of Biology Education, FTTE, University of Muhammadiyah Malang, Indonesia

\section{INTRODUCTION}

Universities are the highest institutions of formal education that play an important role in producing qualified graduates. A university can be said successful if able to guarantee its graduates to be able to improve the quality of their life (Hassanbeigi et al., 2011; Pereira \& Costa, 2017). Therefore, universities should accommodate their students, both empowering the mastery of science concepts (Hassanbeigi et al., 2011) as well as achieving the various skills needed in the $21^{\text {st }}$-century (Ghazivakili et al., 2014; Pereira \& Costa, 2017). Every department in every faculty of a university must achieve these goals, including the Department of Chemistry Education.

The Faculty of Tarbiyah and Science Education is one the faculty at State Islamic Institute of Batusangkar that has Department of Chemistry Education. In this department, students will take various courses. In general, the courses facilitate the students to explore various chemical concepts. Related to chemistry concepts, according to Barke (Barke, Hazari, \& Yitbarek, 2009), chemical learning is one of the lessons that has some abstract concepts and difficult to understand. The example of abstract concepts, such as the concept of atoms, a chemical bond, nomenclature of chemistry, the concentration and chemical equilibrium. Some of the chemistry concepts also often generate misconception, such as the chemical bond, chemical equilibrium and reduction-oxidation reaction (Barke et al., 2009).

Beside of various courses related to chemistry, chemistry education students must also take General Biology course. General Biology course is one of the compulsory subjects in the Department of Biology Education which is also available in the Department of Chemical Education at State Islamic Institute of Batusangkar. The students are taking the course which has 2 credits (16 meeting) during the first semester. There are some topics which studied in General Biology 
course. One of the topics is ecosystem, environmental education that describe and analyse the understanding of the biosphere, the earth and its living things.

Chemistry and biology are two interrelated branches of science (Boltax, Armanious, Kosinski-Collins, \& Pontrello, 2015; Ebetino et al., 2011; Hruby, 2009; Pross, 2009). Both of them are studying various natural phenomena and have important role in human life. Various courses of biology are required to be the basis for the understanding of some chemical concepts, as well as some chemistry courses related to several concepts of Biology.

In contrast, the character of several biological concepts have a difference in the chemical concepts characteristics. Biology is the science of life that studying the symptoms and the processes of life (Rustaman, 2016). Moreover, Biology is one of the science subjects which actively developed. The everexpanding of biology is focused on learning, from micro to macro levels, leads students to receive a wide range of topics and abstract concepts. Furthermore, Biology is not only concerning to mastery knowledge but also studying the process of discovery that emphasizes the direct experience (Hayati \& Berlianti, 2016). Various concepts of biology are discovered and developed by researchers through scientific methods involving model organisms, so that biology learning should be directed toward students to gain knowledge through the stages of the scientific method.

Related to its characteristics, various types of learning alternatives are recommended in biology learning. To deal with many of the concepts studied, some previous research recommends the implementation of some learning models, such as cooperative script, reciprocal teaching (Fauzi, 2013; Ramadani, Fauzi, Sukmawati, \& Corebima, 2015; Sukmawati, Ramadani, Fauzi, \& Corebima, 2015), and problem based learning (Bidokht \& Assareh, 2011; Nazir \& Zabit, 2010; Permana, Suwono, \& Listyorini, 2016; Savery, 2006).To deal with the abstract of the concept and the difficulty of understanding the style of the language in reference, especially Foreign Language references, the educators are encouraged to develop various media and learning resources (Fauzi, 2017; Widiansyah, Indriwati, Munzil, \& Fauzi, 2018). The use of a variety of model organisms is also recommended as an alternative that teachers can use it to overcome the abstract of biological concepts, in addition to improving students' learning motivation and student skills (Fauzi \& Corebima, 2016c, 2016a, 2016b; Fauzi, Corebima, \& Zubaidah, 2016; Fauzi \& Ramadani, 2017). Finally, related to the efforts of teachers in empowering $21^{\text {st }}$-century skills, the implementation of cooperative learning can be used as an alternative form of learning held during Biology learning (Buku, Mite, Fauzi, Widiansyah, \& Anugerah, 2015; Ramadani et al., 2015).

However, based on pre-research or in the first meeting that has been done on students at the Department of Chemistry Education who have taken the course of General Biology, some students said several concepts in the course are classified as elusive. The concepts are too theoretical and less contextual so it is difficult to understand and this condition can be carved on the teaching and learning process. Moreover, there are various problems encountered, such as students are less interest in reading books, less search for reference materials, as well as students are still low in their independence and mentality especially in compiling the sentence in question and answer. It showed that the power of the analysis is still low. Furthermore, it can be seen that the students' scientific attitude (i.e. curiosity, cooperation, accuracy, responsibility, and critical thinking) is also still not optimal.

Several previous studies have reported student responses to courses that have different characteristics than the common courses in their department (Anggraini, 2016; Sudaryanto \& Purwanti, 2009). However, these previous studies examined the response of other major students towards chemistry course, not vice versa. Research that examines the chemistry student's response to biology lectures has not yet been found. The existing research is limited to optimizing the process of biology course in the Department of Chemistry Education (Subiantoro, Paidi, \& Ariyanti, 2012).

In addition, based on students' responses from pre-research that previously described, the temporary conclusion is: Department of Chemistry Education students feel difficulty and less interested on General Biology course. Such information needs to be validated through more systematic and in-depth study. So, the aim of this study is to obtain the information about the response of chemical education students in the implementation of the General Biology 
course. This research is expected to contribute: a) as a basic data for the development of general biology learning especially in the implementation of future lectures; and b) provide information about the response of students in the implementation of General Biology course.

Students' assumptions about a course will have an impact on their learning motivation in the course. Motivation to learn is one of the main factors that influence the involvement of students in the lecture process (Filak \& Sheldon, 2008; Widiansyah et al., 2018). The higher frequency of student involvement in learning process, the more optimal achievement of their learning outcome (Gunuc, 2014). Therefore, the information about the response of students to the General Biology course can be used as a basis to reflect on how the process of General Biology course from the student's point of view.

\section{METHOD}

This research was conducted at the Faculty of Tarbiyah and Sciences Education, State Islamic Institute of Batusangkar which is located on Jl. Jenderal Sudirman No. 137 Lima Kaum, Batusangkar, West Sumatera. The research was conducted from August to December 2017. The subjects of this research were all first semester students at Department of Chemistry Education who take General Biology course, with a total of 24 respondents/students. This research was descriptive research that was interpreting and telling data about student response on General Biology course in the Department of Chemistry Education. The instrument that used in this research was a questionnaire on the General Biology course.

There were eight aspects asked in the questionnaire used: (1) the attractiveness of biology lectures; (2) suitability of the lecturing process with lecture plan; (3) ease of understanding of learned concepts; (4) utilization of instructional media; (5) empowering critical thinking skills during lectures; (6) challenges during lectures; (7) transparency of the assessment and evaluation; and (8) suitability of evaluation questions with learning outcomes. Each aspect has two responses, yes and no. The response result is used as the basis for data analysis in this study.
The response scoring in this study using the guidance presented in Table 1.

Table 1. Assessment of student response

\begin{tabular}{cc}
\hline Answer & Value/score \\
\hline Yes (Y) & 1 \\
No $(\mathrm{N})$ & 0 \\
\hline
\end{tabular}

(Source: Riduwan, 2011)

Scores obtained on each aspect of each student are then summed and converted in percentage form. Conversions in percentage form are based on formula 1 (Huda, 2013).

$\mathrm{P}=(\mathrm{E} / \mathrm{N}) \times 100 \%$

Information:

$\mathrm{P}=$ Percentage of respondents' answers

$\mathrm{E}=$ Number of respondents' answers

$\mathrm{N}=$ Number of respondents

As the percentage obtained, it was then matched to the guidance criteria (see Table 2).

Table 2. Criteria for student response

\begin{tabular}{cc}
\hline Percentage $(\%)$ & Category \\
\hline $86-100$ & Very good \\
$76-85$ & Good \\
$60-75$ & Enough \\
$0-59$ & Not good \\
\hline
\end{tabular}

\section{RESULT AND DISCUSSION}

The results represent the response of Chemistry Education students to the General Biology course. The results are presented in Table 3. The General Biology lecture was not included in the "very good" category. This result relates to the condition of the learning in which most students have low interest to the material being presented. This condition due to the biological concepts discussed in General Biology course have more theories than practice. This result is line with Aji who explained that the General Biology course has a material that is classified as an elusive level (Prasetiyo \& Perwiraningtyas, 2017). The concepts are more theoretical than contextual learning. The attractiveness of biology course can actually be improved through several ways, such as the use of model organisms (Fauzi et al., 2016; Fauzi \& Ramadani, 2017) and other learning media (Widiansyah et al., 2018).

Furthermore, there were $75 \%$ of 24 students who say the material that has been delivered is in accordance with the semester's learning plan 
that has been made by the lecturer. Semester Learning Plan (SLP) is a projection of activities (activities) that will be conducted by lecturers with students in the process of learning or lectures in the classroom (Nurdin, 2017). Therefore, SLP is an integral part that cannot be separated from "learning or lecture". This means every lecturer who will conduct learning process must prepare a learning plan firstly.

Table 3. Student response to general biology courses.

\begin{tabular}{|c|c|c|}
\hline No. & Statement & $\begin{array}{c}\text { Percentage } \\
(\%)\end{array}$ \\
\hline 1 & $\begin{array}{l}\text { Is the general biology course } \\
\text { very interesting? }\end{array}$ & 60 \\
\hline 2 & $\begin{array}{l}\text { Are the materials being studied } \\
\text { in accordance with the planning } \\
\text { of the general biology course? }\end{array}$ & 75 \\
\hline 3 & $\begin{array}{l}\text { Do these biology easily } \\
\text { understandable? }\end{array}$ & 71 \\
\hline 4 & $\begin{array}{l}\text { Is the learning media used to } \\
\text { help understand the material in } \\
\text { learning? }\end{array}$ & 88 \\
\hline 5 & $\begin{array}{l}\text { Do these general biology } \\
\text { courses train the ability to think } \\
\text { critically? }\end{array}$ & 72 \\
\hline 6 & $\begin{array}{l}\text { Have assignments give } \\
\text { challenges in learning? }\end{array}$ & 92 \\
\hline 7 & $\begin{array}{l}\text { Are assessments and } \\
\text { evaluations implemented in a } \\
\text { transparent manner? }\end{array}$ & 96 \\
\hline \multirow[t]{2}{*}{8} & $\begin{array}{l}\text { Do the test questions match the } \\
\text { competencies demanded? }\end{array}$ & 88 \\
\hline & Average & 79.6 \\
\hline
\end{tabular}

At the level of understanding, the student's response to General Biology is at the "enough" level, rather than being "good" or "very good". These results indicate that students feel difficulties to learn Biological concepts. This condition is in line with some previous studies that reported that Biology contains several concepts that are not easy to learn (Çimer, 2012; Etobro \& Fabinu, 2017). Although these previous reports were not positioning Chemistry Education students as the subject of his research, the reported information has proven that Biology is sometimes difficult to learn.

Then, $88 \%$ of students said that the media can help to understand the material in the learning process of the General Biology course. The use of media is essential in the learning process (Susilana \& Riyana, 2009). The existence of learning media can assist the task of teachers in delivering messages from the lesson material given by the teacher to the students The use of appropriate media in biology learning is one of the solutions of various problems related to student's interest, learning outcomes and motivation (Fauzi, 2017; Suhartono, 2015; Widiansyah et al., 2018). The utilization of appropriate media will increase students' attention and motivation on the topics to be studied. This condition gives an impact on students to be more concentrated and student achievement can be improved (Purwono, Yutmini, \& Anitah, 2014).

The very important role of learning media is to motivate students, provide experience and facilitate students in understanding the material presented (Chen \& Chen, 2011; Walker, 2003). It can be concluded that the lecturers are effective in using the media and it can increase student interest in teaching and learning process and students will be faster and easier to understand and understand the material presented by lecturers.

Furthermore, $72 \%$ of students assume that General Biology lectures can train students' critical thinking skills. Critical thinking is the ability of evaluative thinking that shows the human ability to see the gap between reality and truth and able to analyze and evaluate as well as to solve the problem (Ennis, 2011; Phan, 2010; Sykes, Wills, Rowlands, \& Popple, 2013). Critical thinking is also the ability to apply the concepts that have been learned in class on various phenomena encountered both at school, at home, and in social life in accordance with the norms that apply (Rachmadtullah, 2015). Critical thinking is one of thinking ability. Thinking ability is obtained from the ability of students to convey questions and answers during the learning process. This skill is one of the skills needed in the 21st Century and Biology educators should be able to empower these skills during the learning process (Ghazivakili et al., 2014; Phan, 2010).

Then, $92 \%$ of the students also stated that the lecture assignments given to the General Biology lectures can challenge them. Students need to be challenged to stimulate the learning process. Through assignments, it can be realized (Scager, Akkerman, Pilot, \& Wubbels, 2017). In addition, assignments can also improve student engagement in the learning process (Buijs \& Admiraal, 2013).

The next, $96 \%$ of students responded that the assessment was done transparently. This information indicates before the tests 
conducted, the lecturer has explained how the weight of the question or the test will be given and the test results are returned to students. Assessment is an activity to provide continuous and comprehensive information about the process and results achieved by students (Fadillah, 2017). The assessment of learning outcomes of learners is very important, because it can give an information about how much learners mastered the competence or material that has been taught by the teacher (Lile \& Bran, 2014). The assessment is the process of interpreting the measurement data on the process and learning outcomes in the form of a score by converting it into a value based on some certain to make a decision about the learning process.

While the student's response to the test items, $88 \%$ of students said the items of the test is in accordance with the competence. Teachers must have the skills and experience in preparing various forms of questions and each kind of question is not only suitable for measuring one particular type of ability (Tofade, Elsner, \& Haines, 2013). Tests are generally used to assess and measure student learning outcomes, especially cognitive learning outcomes regarding the mastery of teaching materials in accordance with education and learning at that time (Widyantoro, 2009).

Various factors affect the student learning outcomes in certain courses. One of the main factors is the students' learning motivation (Filak \& Sheldon, 2008; Widiansyah et al., 2018). The level of motivation to learn will determine how high the effort of students to get involved in the learning process. This condition is influenced by the student's assumption of the course. The better of student response effect on the better of student involvement in the lecturing process. This condition tends the student to obtain optimal academic achievement (Gunuc, 2014)

Based on the results obtained from this study, a positive response is shown by Department of Chemistry Education students on the General Biology course. This information indicates, although biological characteristics are different from chemistry, the students still have the potential to obtain optimal learning outcomes in this course. The results of this study can also be used as a basis for improving the quality of the General Biology course so students' positive responses to the General Biology course can be increased.

\section{CONCLUSION}

The result of this study is the average percentage of student response to the General Biology course was $79.6 \%$. The result indicates the response of chemical education student who has taken course in General Biology in State Islamic Institute of Batusangkar as good criteria. Biology is sometimes regarded as a difficult and less interesting learning. The use of learning media or learning model can be used as an alternative to overcome the problems in the process of learning Biology, including in General Biology course.

In this study, students gave positive responses to the General Biology course, although the positive response is still not optimal. This information indicates that students have the potential to obtain good learning outcomes in the General Biology course. This potency can still be optimized. Therefore, it is recommended to improve the quality of the General Biology course, especially on the aspects that the percentage of student's positive response is lower than other aspects.

\section{REFERENCES}

Anggraini, D. P. (2016). Analisis kesulitan mahasiswa dalam perkuliahan dan praktikum Kimia Dasar di Jurusan Pendidikan Biologi FKIP UNISBA. Konstruktivisme, 8(1), 61-71.

Barke, H.-D., Hazari, A., \& Yitbarek, S. (2009). Misconceptions in Chemistry. Berlin: Springer-Verlag. https://doi.org/10.1007/9 78-3-540-70989-3

Bidokht, M. H., \& Assareh, A. (2011). Lifelong learners through problem-based and self directed learning. Procedia Computer Science, 3, 1446-1453. https://doi.org/10 .1016/j.procs.2011.01.028

Boltax, A. L., Armanious, S., Kosinski-Collins, M. S., \& Pontrello, J. K. (2015). Connecting biology and organic chemistry introductory laboratory courses through a collaborative research project. Biochemistry and Molecular Biology Education, 43(4), 233-244. https://doi. org/10.1002/ bmb.20871

Buijs, M., \& Admiraal, W. (2013). Homework assignments to enhance student engagement in secondary education. European Journal of Psychology of 
Education, 28(3), 767-779. https://doi. org/10.1007/s10212-012-0139-0

Buku, M. N. I., Mite, Y., Fauzi, A., Widiansyah, A. T., \& Anugerah, D. Y. (2015). Penerapan pembelajaran cooperative script berbasis lesson study sebagai upaya peningkatan keaktifan lisan dan kecakapan sosial mahasiswa SI Pendidikan Biologi matakuliah strategi belajar mengajar. In Proceedings of the 2nd Seminar \& Workshop Nasional Biologi, IPA, dan Pembelajarannya FMIPA UM (pp. 603-606). Malang: Biologi FMIPA UM.

Chen, C.-C., \& Chen, C.-M. (2011). The application of interactive media display technology in environmental science learning (pp. 484-488). Springer, Berlin, Heidelberg. https://doi.org/10.1007/978-3642-22095-1_97

Çimer, A. (2012). What makes biology learning difficult and effective: Students' views. Educational Research and Reviews, 7(3), 61-71. https://doi.org/10.5897/ERR11.205

Ebetino, F. H., Hogan, A. M. L., Sun, S., Tsoumpra, M. K., Duan, X., Triffitt, J. T., .. Russell, R. G. G. (2011). The relationship between the chemistry and biological activity of the bisphosphonates. Bone, 49(1), 20-33. https://doi.org/10. 1016/j.bone.2011.03.774

Ennis, R. H. (2011). The Nature of Critical Thinking: An Outline of Critical Thinking Dispositions and Abilities.

Etobro, A. B., \& Fabinu, O. E. (2017). Students Perceptions of Difficult Concepts in Biology in Senior Secondary Schools in Lagos State. Global Journal of Educational Research, 16, 139-147.

Fadillah, E. N. (2017). Pengembangan instrumen penilaian untuk mengukur keterampilan proses sains siswa SMA. Didaktika Biologi, 1(2), 123-134.

Fauzi, A. (2013). Pengaruh Kemampuan Akademik terhadap Keterampilan Metakognitif, Hasil Belajar Biologi, dan Retensi Siswa SMA Kelas $X$ dengan Penerapan Strategi Pembelajaran Cooperative Script Di Malang. Universitas Negeri Malang. https://doi. org/10.13140/RG.2.2.24659.99363

Fauzi, A. (2017). Analisis filogeni Tarsius tarsier form Buton dengan beberapa spesies tarsius dari Sulawesi Tengah, Sumatera-Kalimantan, dan Filipina atas dasar Gen MT-CO2 sebagai bahan pengembangan buku panduan penelitian Mata Kuliah Genetika II di Universitas Negeri Mal. Universitas Negeri Malang.

Fauzi, A., \& Corebima, A. D. (2016a). Fenomena gagal berpisah, epistasis, dan nisbah kelamin pada Drosophila melanogaster. In Seminar Nasional Biologi 2016 (pp. 283-288). Surabaya: Universitas Negeri Surabaya.

Fauzi, A., \& Corebima, A. D. (2016b). Pemanfataan Drosophila melanogaster sebagai organisme model dalam mempelajari Hukum Pewarisan Mendel. In Seminar Nasional Biologi 2016 (pp. 372-377). Surabaya: Universitas Negeri Surabaya.

Fauzi, A., \& Corebima, A. D. (2016c). Pemanfataan Drosophila melanogaster sebagai organisme model dalam mengungkap berbagai fenomena penyimpangan rasio Mendel. In Seminar Nasional Biologi 2016 (pp. 278-282). Surabaya: Universitas Negeri Surabaya.

Fauzi, A., Corebima, A. D., \& Zubaidah, S. (2016). The utilization of ferns as a model organism for studying natural polyploidization concept in genetics course. In International Conference on Education (pp. 51-58). Malang: Universitas Negeri Malang.

Fauzi, A., \& Ramadani, S. D. (2017). Learning the genetics concepts through project activities using Drosophila melanogaster : a qualitative descriptive study. JPBI (Jurnal Pendidikan Biologi Indonesia), 3(3), 238-247. https://doi.org/10.22219/ jpbi.v3i3.4540

Filak, V. F., \& Sheldon, K. M. (2008). Teacher support, student motivation, student need satisfaction, and college teacher course evaluations: testing a sequential path model. Educational Psychology, 28(6), 711-724. https://doi.org/10.1080/0144341 0802337794

Ghazivakili, Z., Norouzi Nia, R., Panahi, F., Karimi, M., Gholsorkhi, H., \& Ahmadi, Z. (2014). The role of critical thinking skills and learning styles of university students in their academic performance. Journal of Advances in Medical Education \& Professionalism, 2(3), 95-102.

Gunuc, S. (2014). The relationships between student engagement and their academic achievement. International Journal on 
New Trends in Education and Their Implication, 5(4), 216-231.

Hassanbeigi, A., Askari, J., Nakhjavani, M., Shirkhoda, S., Barzegar, K., Mozayyan, M. R., \& Fallahzadeh, H. (2011). The relationship between study skills and academic performance of university students. Procedia-Social and Behavioral Sciences, 30, 1416-1424. https://doi.org /10.1016/j.sbspro.2011.10.276

Hayati, N., \& Berlianti, N. A. (2016). Improvement Students' Activities and Cognitive learning outcomes of hasyim asy'ari university through guided discovery learning. JPBI (Jurnal Pendidikan Biologi Indonesia), 2(3), 206214.

Hruby, V. J. (2009). Organic chemistry and biology: Chemical biology through the eyes of collaboration. Journal of Organic Chemistry, 74(24), 9245-9264. https://doi. org/10.1021/jo901767e

Huda, M. S. (2013). Pengembangan modul pembelajaran thermal radiation untuk menunjang perkuliahan perpindahan panas mahasiswa D3 Teknik Mesin FT UNESA. Jurnal Pendidikan Teknik Mesin, 2(1), 15-23.

Lile, R., \& Bran, C. (2014). The Assessment of Learning Outcomes. Procedia-Social and Behavioral Sciences, 163, 125-131. https: //doi.org/10.1016/j.sbspro.2014.12.297

Nazir, M., \& Zabit, M. (2010). Problem-based learning on students' critical thinking skills in teaching business education in Malaysia: A literature review. American Journal of Business Education, 3(6), 19 32.

Nurdin, S. (2017). Pengembangan kurikulum dan rencana pembelajaran semester (RPS) berbasis KKNI di perguruan tinggi. Jurnal Al-Fikrah, (1), 21-30.

Pereira, O. P., \& Costa, C. A. A. T. (2017). The importance of soft skills in the university academic curriculum: The perceptions of the students in the new society of knowledge. International Journal of Business and Social Research, 07(03), 2534. https://doi.org/http://dx.doi.org/10.185 33/ijbsr.v7i6.1052 The

Permana, T. I., Suwono, H., \& Listyorini, D. (2016). Pengaruh pembelajaran berbasis masalah penyakit tropis terhadap kecakapan hidup siswa SMA. Jurnal Pendidikan: Teori, Penelitian, Dan
Pengembangan, 1(6). Retrieved from https://scholar.google.co.id/citations?hl=e n\&user=Eh-8zbkAAAAJ

Phan, H. P. (2010). Critical thinking as a selfregulatory process.

Prasetiyo, A.., \& Perwiraningtyas. (2017). Pengembangan buku ajar berbasis lingkungan hidup pada matakuliah biologi di Universitas Tribhuwana Tunggadewi. JPBI (Jurnal Pendidikan Biologi Indonesia), 3(1), 19-27.

Pross, A. (2009). Seeking the chemical roots of Darwinism: Bridging between chemistry and biology. Chemistry-A European Journal, 15(34), 8374-8381. https://doi. org/10.1002/chem.200900805

Purwono, J., Yutmini, S., \& Anitah, S. (2014). Penggunaan media audio-visual pada mata pelajaran Ilmu Pengetahuan Alam di Sekolah Menengah Pertama Negeri 1. Jurnal Teknologi Pendidikan Dan Pembelajaran, 2(2), 18.

Rachmadtullah, R. (2015). Kemampuan berpikir kritis dan konsep diri dengan hasil belajar pendidikan kewarganegaraan siswa kelas v sekolah dasar. JPD - Jurnal Pendidikan Dasar, 6(2), 287-298. https://doi.org/10.21009/JPD.062.10

Ramadani, S. D., Fauzi, A., Sukmawati, I., \& Corebima, A. D. (2015). Perbandingan potensi strategi pembelajaran cooperative script dan reciprocal teaching dalam memberdayakan keterampilan metakognitif, hasil belajar Biologi, dan retensi siswa SMA. In Proceedings of the 2nd Seminar \& Workshop Nasional Biologi, IPA, dan Pembelajarannya FMIPA UM (pp. 655-661). Malang: Biologi FMIPA UM.

Riduwan. (2012). Skala pengukuran variabelvariabel penelitian. Bandung: Alfabeta.

Rustaman, N. Y. (2016). Pembelajaran sains masa depan berbasis STEM education. In S. Susanti, A. Maizeli, \& M. M. Zural (Eds.), Prosiding Seminar Nasional Biologi Edukasi 12016 (pp. 1-17). Padang: Program Studi Pendidikan Biologi STKIP PGRI Sumatera Barat.

Savery, J. R. (2006). Overview of problembased learning: Definitions and distinctions. Interdisciplinary Journal of Problem-Based Learning, 1(1), 13. https://doi.org/10.7771/1541-5015.1002

Scager, K., Akkerman, S. F., Pilot, A., \& Wubbels, T. (2017). Teacher dilemmas in 
challenging students in higher education. Teaching in Higher Education, 22(3), 318-335. https://doi.org/10.1080/1356251 7.2016.1248392

Subiantoro, A. W., Paidi, \& Ariyanti, N. A. (2012). Lesson study dalam perkuiahan Biologi Umum dengan socioscientific issues-based instruction untuk character building. In Seminar Nasional $X$ Pendidikan Biologi FKIP UNS (p. 90=96).

Sudaryanto, A., \& Purwanti, O. S. (2009). Persepsi mengenai pembelajaran kimia pada mahasiswa keperawatan. In $\mathrm{S}$. Mulyani, N. Y. Indriyanti, \& E. Susanti (Eds.), Prosiding Seminar Nasional Kimia dan Pendidikan Kimia (pp. 122-127). Surakarta: Program Studi Pendidikan Kimia Jurusan Matematika dan Ilmu Pengetahuan Alam Fakultas Keguruan dan Ilmu Pendidikan Universitas Sebela Maret Surakarta.

Suhartono, B. P. (2015). Pengembangan multimedia interaktif berbasis flash untuk meningkatkan hasil belajar siswa pada pembelajaran Sistem Imun untuk kelas XI SMA. Universitas Negeri Malang.

Sukmawati, I., Ramadani, S. D., Fauzi, A., \& Corebima, A. D. (2015). Perbedaan pemberdayaan retensi antara siswa sma akademik rendah dan tinggi melalui pembelajaran cooperative script dalam pembelajaran biologi. In Proceedings of the 2nd Seminar \& Workshop Nasional Biologi, IPA, dan Pembelajarannya
FMIPA UM (pp. 662-667). Malang: Biologi FMIPA UM.

Susilana, R., \& Riyana, C. (2009). Media pembelajaran. Bandung: CV Wacana Prima.

Sykes, S., Wills, J., Rowlands, G., \& Popple, K. (2013). Understanding critical health literacy: a concept analysis. BMC Public Health, 13(1), 150. https://doi.org/10.11 86/1471-2458-13-150

Tofade, T., Elsner, J., \& Haines, S. T. (2013). Best practice strategies for effective use of questions as a teaching tool. American Journal of Pharmaceutical Education, 77(7), 1-9. https://doi.org/10.5688/ajpe 777155

Walker, D. E. T. (2003). The importance of media in the classroom. In What Every Teacher Should Know About Media and Technology (pp. 1-7).

Widiansyah, A. T., Indriwati, S. E., Munzil, \& Fauzi, A. (2018). I-invertebrata as an android-based learning media for molluscs, arthropods, and echinoderms identification and its influence on students' motivation. JPBI (Jurnal Pendidikan Biologi Indonesia), 4(1), 4352.https://doi.org/10.22219/jpbi.v4i1.5476

Widyantoro, D. (2009). Pengembangan soal tes pilihan ganda kompetensi sistem starter dan pengisian program keahlian teknik mekanik otomotif Kelas XII. Jurnal Pendidikan Teknik Mesin, 9(1), 14-21. 